\title{
Antibacterial activity of Schinopsis brasiliensis against phytopathogens of agricultural interest
}

\section{Atividade antibacteriana de Schinopsis brasiliensis contra fitopatógenos de interesse na agricultura}

\author{
${ }^{1}$ Poliana G. Guimarães; ${ }^{2}$ Indiana S. Moreira; ${ }^{2}$ Pedro C. Campos Filho; ${ }^{2}$ José Lucas de A. A. Ferraz; \\ ${ }^{3}$ Quelmo S. de Novaes; ${ }^{4 *}$ Ronan Batista \\ ${ }^{1}$ Department of Human Sciences and Technology, Bahia State University, Campus XXII, Brazil. \\ ${ }^{2}$ Department of Basic and Instrumental Studies, State University of Southeast of Bahia, Brazil. \\ ${ }^{3}$ Department of Plant and Animal Science, State University of Southeast of Bahia, Brazil. \\ ${ }^{4}$ Department of Organic Chemistry, Institute of Chemistry, Federal University of Bahia, Brazil. \\ Correspondência: ronbatis@ufba.br
}

\section{Resumo}

O objetivo deste trabalho foi avaliar a atividade antimicrobiana in vitro da planta Schinopsis brasiliensis contra alguns fitopatógenos de interesse na agricultura. Extratos etanólicos foram obtidos e ensaiados contra o fungo Fusarium solani e bactérias do gênero Xanthomonas, Pectobacterium, Ralstonia e Acidovorax. Os resultados mostraram, em geral, um bom desempenho destes extratos contra as bactérias ensaiadas, com valores de concentração inibitória mínima entre 312,5 e 10.000 $\mu \mathrm{g} \cdot \mathrm{mL}^{-1}$. Além disso, um triterpeno (glutinol) e um pirocatecol são relatados como constituintes químicos desta espécie. Conclui-se que $S$. brasiliensis apresenta potencial para ser usado no controle de doenças de plantas causadas pelas bactérias pertencentes aos gêneros Xanthomonas, Ralstonia e Acidovorax.

Palavras-chave: fitopatógenos; Schinopsis brasiliensis; glutinol; pirocatecol; Artemia salina; agricultura.

\begin{abstract}
The aim of this work was to evaluate the in vitro antimicrobial activity of Schinopsis brasiliensis against certain phytopathogens of agricultural interest. Ethanolic crude extracts were obtained and assayed against Fusarium solani and bacteria pertaining to the genera Xanthomonas, Pectobacterium, Ralstonia and Acidovorax using the broth micro-dilution technique. The results demonstrated a good aptitude of $S$. brasiliensis extracts to inhibit growth of the majority of the evaluated phytopathogenic bacteria, with MIC values in the range from 312.5 to $10,000 \mu \mathrm{g} \cdot \mathrm{mL}^{-1}$. Moreover, triterpene glutinol and a pyrocatechol are shown to be the chemical constituents of $S$. brasiliensis. The results suggest that $S$. brasiliensis has the potential for agricultural use to control plant diseases
\end{abstract}


caused by phytopathogenic bacteria belonging to the genera Xanthomonas, Ralstonia and Acidovorax.

Keywords: phytopathogens; Schinopsis brasiliensis; glutinol; pyrocatechol; Artemia salina; agriculture.

\section{Introdução}

Recent estimates indicate that the world's population is expected to expand from the current 6.7 billion to 9 billion by 2050 (Ronald, 2011). Global food production is not increasing fast enough to support this rapidly growing population; therefore, it is believed that world agricultural production needs to increase $50 \%$ by 2030 to accommodate this higher demand for food (Ronald, 2011; Davies et al., 2009). Diseases of crop plants are among the most important constraints in the production of adequate quantities of food, committing up to a third of the world production (Khan, 2008; Agrios, 2005). Therefore, a reduction in the losses of crops to pests and phytopathogens is understood to be equivalent to creating more land and more water to increase real agricultural production (Ronald, 2011).

Pesticides are widely used to control plant diseases around the world (Khamna, Yokota and Lumyong, 2009). Although the use of such products has a positive short-term effect for the producer, their longterm employment has many negative effects for society and the environment, such as the pollution of soil and water, deposition of agrochemical residues on food and the emergence of resistant pathogens, among others (Khamna, Yokota and Lumyong, 2009; Stangarlin et al., 1999; Kimati et al., 1997).

To reduce the negative effects of pesticides, natural alternatives are being searched for the control of phytopathogens. Within this context, there is an intense and increasing current search for new antimicrobial agents from plants as a result of the growing resistance of pathogenic microorganisms to synthetic products (Amaral and Bara, 2005).

According to Di Piero, Novaes and Pascholati (2010) one valid alternative is to exploit the biological activity of secondary metabolites available in crude plant extracts and essential oils from medicinal plants of native flora. In this connection, some examples can be found in the literature, from which we select three ones: 1. In vitro control of the fungi Colletotrichum gloeosporioides, C. musae and Fusarium subglutinans $\mathrm{f}$. sp. ananas by the essential oils of Cymbopogon nardus, C. citratus and Eucalyptus citriodora (Alves et al., 2003); 2. Control of anthracnose in guava fruit (Psidium guajava $\mathrm{L}$.) by the aqueous extract and essential oil of cloves (Syzygium aromaticum) (Rozwalka et al., 2008); 3. Control of common bacterial blight in bean plants by bushy matgrass (Lippia Alba) and pepper-rosmarin (Lippia sidoides) tinctures and the essential oils of rosemary (Rosmarinus officinalis) and cinnamon (Cinnamomum zeylanicum) (Vigo et al., 2009).

Schinopsis brasiliensis Engl. (Anacardiaceae) is the most important species representing the genus Schinopsis native to Brazil (Saraiva et al., 2011; Albuquerque et al., 2007). An endemic tree popularly known as "braúna" or "baraúna" (Albuquerque et al., 2007; Cardoso, David and David, 2005), it is typical of the Caatinga and of high economic value to the Northeast region (Albuquerque et al., 2007). The antibacterial activity of baraúna extracts against resistant strains of Staphylococcus aureus has been reported (Saraiva et al., 2011). Furthermore, few phytochemical studies have been conducted with this 
plant, of which we highlight the isolation of a few alkyl and alkenyl phenols, among other components (Cardoso, David and David, 2005).

Schinopsis brasiliensis extracts have shown antibacterial action against microorganisms pathogenic to human beings and are considered to be a plant species with a potential use in phytopathogen control. As no research until this moment has described the antimicrobial effect of this plant against phytopathogenic microorganisms, the purpose of this work was to assess the antimicrobial activity of Schinopsis brasiliensis extracts against some phytopathogenic agents with important economic value for agriculture. Therefore, the $S$. brasiliensis extracts were tested against the fungus Fusarium solani, a causative agent of root rot of potatoes and beans; as well as against the phytopathogenic Xanthomonas bacteria: Xanthomonas campestris PV (pv). Campestris and Xanthomonas campestris pv. viticola, which causes black rot in crucifers and bacterial canker in grapevines, respectively. In addition, the phytobacteria Pectobacterium carotovorum subsp. carotovorum, which causes soft rot in greenery; Ralstonia solanacearum, which causes bacterial wilt in banana trees and green peppers; and Acidovorax avenae subsp. citrulli, responsible for bacterial spot in melons were also assayed. At last, the ecotoxicity potential of $S$. brasiliensis extracts was assessed by means of brine shrimp lethality (BSL) bioassay against Artemia salina.

\section{Material and Methods}

\subsection{Plant material collection and extract preparation}

The leaves, bark and secondary roots of Schinopsis brasiliensis were collected at the Caatinga Grande ranch, municipal area of Malhada de Pedras, southwest region of Bahia, during the month of June,
2011. An exsiccate was deposited at the UESB herbarium, in Vitória da Conquista city, Bahia state, Brazil, under the code HUESBVC 4124. The different parts were dried separately in a forced air circulation oven at $50^{\circ} \mathrm{C}$ for 48 hours. The dried plant material leaves, bark and secondary roots - was milled and exhaustively extracted with $96 \%$ ethanol by maceration to give, after concentration in a rotary evaporator, the corresponding ethanolic extracts of the leaves (EEL, 12.90g), stems (EES, 11.26g) and roots (EER, 5.58g).

\subsection{Isolation of compounds 1 and 2 from EEL}

A part of the crude ethanolic leaf extract of Schinopsis brasiliensis (EEL, 9.0g) was chromatographed on a silica gel column and eluted with increasingly polar solvent systems, resulting in eleven fractions of $500 \mathrm{~mL}$ each: two from hexane (Frs. 1-2), four from dichloromethane (Frs. 3-6), four from ethyl acetate (Frs. 7-10) and one from methanol (Fr. 11). Fraction 3 (294mg) was rechromatographed on the silica gel column and eluted with increasingly polar mixtures of hexane and ethyl acetate, resulting in forty-six subfractions of $10 \mathrm{~mL}$ each. Sub-fraction 11, eluted with hexane-ethyl acetate (8:2), afforded substance 1 (10mg), which was pure under TLC and spectroscopic analysis. This substance was identified as triterpene glutinol on the basis of the $\mathrm{IR},{ }^{1} \mathrm{H}$ and ${ }^{13} \mathrm{C}$ NMR data that were identical to those described in the literature (Tuan, Hung and Chien, 2005).

The initial fractionation of EEL was repeated to obtain a larger quantity of the dichlorometanic fractions, which were grouped $(1.0 \mathrm{~g})$ and submitted again to column chromatography on silica gel, employing increasingly polar mixtures of hexane and ethyl acetate as eluents to afford seventy-seven fractions $30 \mathrm{~mL}$ each. Fraction 54, eluted with hexane-ethyl acetate (7:3), provided compound 2 (44mg), which was identified as a pyrocatechol whose IR and NMR data were very similar to those reported for Z,Z-4- 
(heptadeca-8,11-diennyl)-benzene-1,2-diol (Sargent, Wangchareontrakul and Jefferson, 1989).

Glutinol (1). IR, $v_{\max }\left(\mathrm{cm}^{-1}\right): 3445,3391,2930,2850$, 1454, 1361, 1180. ${ }^{1} \mathrm{H} \mathrm{NMR}\left(\mathrm{CDCl}_{3}, 500 \mathrm{MHz}, \delta\right): 5.63$ $(m, 1 \mathrm{H}), 3.47(s, 1 \mathrm{H}), 1.16(s, 3 \mathrm{H}), 1.14(s, 3 \mathrm{H}), 1.04$ (s, 3H), 1.09 (s, 3H), 1.00 (s, 3H), 0.99 (s, 3H), 0.95 $(s, 3 \mathrm{H}), 0.85 .(s, 3 \mathrm{H}) \cdot{ }^{13} \mathrm{C} \mathrm{NMR}\left(\mathrm{CDCl}_{3}, 125 \mathrm{MHz}, \delta\right)$ : 18.2 (C-1), 27.8 (C-2), 76.3 (C-3), 40.8 (C-4), 141.6 (C-5), 122.0 (C-6), 23.6 (C-7), 47.4 (C-8), 34.8 (C-9), 49.7 (C-10), 34.6 (C-11), 30.3 (C-12), 39.3 (C-13), 37.8 (C-14), 32.1 (C-15), 36.0 (C-16), 30.1 (C-17), 43.1 (C-18), 35.1 (C-19), 28.2 (C-20), 33.1 (C-21), 38.9 (C-22), 28.9 (C-23), 25.4 (C-24), 16.2 (C-25), 19.6 (C-26), 18.4 (C-27), 32.0 (C-28), 34.5 (C-29), $32.3(\mathrm{C}-30)$

Pyrocathecol 2. IR, $V_{\max }\left(\mathrm{cm}^{-1}\right): 3375,3008,2924$, 2854, 1604, 1518, 1462, 1373, 1280, 1192, 1114, 956, 864, 786, 721. ${ }^{1} \mathrm{H} \mathrm{NMR}\left(\mathrm{CDCl}_{3}, 500 \mathrm{MHz}, \delta\right)$ : $6.76(d, J=8.0,1 \mathrm{H}), 6.69(t, J=2.0,1 \mathrm{H}), 6.59$ (dd, J $=2.0,8.0 ; 1 \mathrm{H}), 5.35-5.14(m, 4 \mathrm{H}), 2.77(m, 2 \mathrm{H}), 2.48$ $(t, J=8.0,2 \mathrm{H}), 2.06-2.01(m, 4 \mathrm{H}), 1.55(m, 2 \mathrm{H}), 0.89$ $(t, J=7.0,3 \mathrm{H}) \cdot{ }^{13} \mathrm{C}$ NMR $\left(\mathrm{CDCl}_{3}, 125 \mathrm{MHz}, \delta\right): 141.31$ (C-1'), 143.43 (C-2'), 115.44 (C-3'), 136.10 (C-4'), 120.61 (C-5'), 115.16 (C-6'), 35.23 (C-1), 31.88 (C-2), $29.68\left(\mathrm{CH}_{2}\right), 29.40\left(\mathrm{CH}_{2}\right), 29.30\left(\mathrm{CH}_{2}\right), 27.20\left(\mathrm{CH}_{2}\right)$, $130.11(\mathrm{CH}), 127.92(\mathrm{CH}), 25.62\left(\mathrm{CH}_{2}\right), 128.00(\mathrm{CH})$, $130.20(\mathrm{CH}), 29.23\left(\mathrm{CH}_{2}\right), 31.57\left(\mathrm{CH}_{2}\right), 22.66\left(\mathrm{CH}_{2}\right)$, $14.09\left(\mathrm{CH}_{3}\right)$.

\subsection{Antifungal assay}

For the antifungal evaluation of the extracts, the fungus Fusarium solani isolated from passion fruit trees and kept at the UESB Phytopathology Laboratory at the Vitória da Conquista campus was used. Fusarium solani colonies were grown on 90$\mathrm{mm}$ Petri dishes containing potato-dextrose-agar (PDA) culture medium (Merck). The dishes were placed in Biochemical Oxygen Demand (BOD) incubation at $25^{\circ} \mathrm{C}$ for seven days to allow the fungus to colonize the entire diameter of the dish.

Extracts EEL, EES and EER (200mg each) were separately diluted in acetone $(5 \mathrm{~mL})$ and topped with off distilled, autoclaved water $(20 \mathrm{~mL})$, resulting in solutions each with a $10 \mathrm{mg}^{\mathrm{mL}} \mathrm{m}^{-1}$ concentration. To arrive at the desired concentrations of $0.001 ; 0.005$ $0.01 ; 0.02 ; 0.05 ; 0.1 ; 0.25 ; 0.5$ and $1 \mathrm{mg}^{-\mathrm{mL}^{-1}}$, the solutions obtained from the extracts in PDA were proportionally diluted and placed on Petri dishes. For the negative control without extracts $\left(0 \mathrm{mg}^{\mathrm{mL}} \mathrm{mL}^{-1}\right)$, only PDA medium, distilled and autoclaved water $(20 \mathrm{~mL})$ and acetone $(5 \mathrm{~mL})$ were used.

Following solidification of the culture medium on the Petri dishes containing the concentrations mentioned above, 5-mm discs containing 8-day-old Fusarium solani mycelium were minced to the center of each dish, which were then sealed with plastic film and placed randomly into the incubation chamber at $25^{\circ} \mathrm{C}$. The lowest concentration of extract that inhibited the growth of the test microorganisms was determined to be the Minimum Inhibitory Concentration (MIC) (Ostrosky et al., 2008). This analysis was conducted by measuring the diameters of the colonies (the mean out of two diametrically opposed measurements) every two days, beginning after 48 hours of incubation and lasting for seven days, i.e., until the moment when the control treatment fungus had colonized the entire surface of the culture medium. Potassium phosphite $\left(\mathrm{K}_{2} \mathrm{HPO}_{3}\right)$ was used as the positive control.

\subsection{Antibacterial assay}

To evaluate the antibacterial activity of the $S$ brasiliensis extracts through the broth micro-dilution technique, the following standard bacterium strains were utilized, which were supplied by the Cultures Collection of the Phytopathology Laboratory, Rural Federal University of Pernambuco, with the respective cultures from where they were isolated: 
Xanthomonas campestris pv. campestris (Xcc56) from cabbage leaves; Xanthomonas campestris pv. viticola (Xcv112) from vine branches; Pectobacterium carotovorum subsp. carotovorum (Pcc23) from lettuce leaves; Ralstonia solanacearum (Race 1) (CGH12) from fresh pepper stems; Ralstonia solanacearum (Race 2) (B19) from bananas; and Acidovorax avenae subsp. citrulli (Aac1.12) from yellow melon.

\subsubsection{Preparation of inoculum}

The inoculum was prepared by emulsifying the overnight colonies from an agar Mueller Hinton by diluting a broth culture (Suffredini, Varella and Younes, 2007). A 0.5 McFarland standard (Andrews, 2001) was used for visual comparison to adjust the suspension to a density equivalent to approximately $10^{8}$ colony-forming units per $\mathrm{mL}$ (CFU/mL). Alternatively, the inoculum could be adjusted photometrically. The suspensions of the organisms were diluted in $0.85 \%$ saline or broth to give $10^{8} \mathrm{CFU} / \mathrm{mL}$. The plates were inoculated within $30 \mathrm{~min}$ of standardizing the inoculum to avoid changes in the inoculum density.

\subsubsection{Microdilution broth assay}

The extracts were tested using the microdilution broth assay (MDBA) in sterile conditions, according to the Clinical and Laboratory Standards Institute (2009) (CLSI, $8^{\text {th }}$ Ed.). The assay was adapted for highthroughput conditions using Müeller-Hinton broth (MHB) medium (Difco ${ }^{\mathrm{TM}}$ ) in 96-well microplates. The inoculum was adjusted to $1 \times 10^{8} \mathrm{CFU} / \mathrm{mL}$ with fresh colonies grown on sterilized Müeller-Hinton Agar (MHA) medium (Difco ${ }^{\mathrm{TM}}$ ). The bacterial suspensions at the different concentrations were prepared in $\mathrm{MHB}$ from the $1 \times 10^{8} \mathrm{CFU} / \mathrm{mL}$ stock. A $10 \mu \mathrm{L}$ aliquot of the bacterial suspension was dispensed into the wells containing MHB medium $(45 \mu \mathrm{L})$ and a $45-\mu \mathrm{L}$ aliquot of the extract at different concentrations $(20 ; 10 ; 5$;
$2.5 ; \quad 1.25 ; \quad 0.63 ; 0.31$ and $\left.0.16 \mathrm{mg}^{-1} \mathrm{~mL}^{-1}\right)$. The microplates were incubated at $25^{\circ} \mathrm{C}$ for $24 \mathrm{~h}$. The inhibition of bacterial growth was assessed using 0.01\% Resazurin (7-Hydroxy-3H-phenoxazin-3-one10-oxide, Sigma-Aldrich ${ }^{\circledR}$ ) solution to verify the presence of microbial growth (Suffredini et al., 2004). A pink or red color after the addition of the Resazurin solution indicated the presence of growing viable cells, and a blue color indicated a lack of microbial growth. MIC was determined to be the lowest concentration visually analyzed to effect total growth inhibition. Gentamicin was used as the positive control.

\subsection{Brine Shrimp Lethality Bioassay}

The toxicity bioassay against Artemia salina was conducted according to the procedure described recently (Batista et al., 2009). Brine shrimp eggs were hatched in artificial seawater $(40 \mathrm{~g} / \mathrm{L}$, sea salt). After 24 hours of incubation at warm room temperature (27$30 \stackrel{\circ}{\circ}$ ) under artificial light, the nauplii were collected with a Pasteur pipette and maintained for an additional 24 hours under the same conditions to reach the metanauplii stage. We prepared the solutions by diluting $50 \mathrm{mg}$ of each extract in $1 \mathrm{~mL}$ of dimethylsulphoxide (DMSO). Working in triplicate $12.5,25$ and $50 \mu \mathrm{L}$ aliquots of these solutions were diluted in $5 \mathrm{~mL}$ of previously prepared sea salt solution containing $A$. salina larvae (10-20 metanauplii), thereby obtaining concentrations of 125,250 and $500 \mu \mathrm{g} / \mathrm{mL}$ of EEL, EES and EER extracts. A negative control was prepared with DMSO sea salt solution with only $A$. salina larvae (10-20 metanauplii), and lapachol was used as the positive control. Twenty four hours later, the number of survivors was counted, and the lethal concentration $50 \%\left(\mathrm{LC}_{50}\right)$, defined as the sample concentration that causes the death of $50 \%$ of the larvae, was calculated using Probit analysis with $95 \%$ confidence intervals (Finney, 1971). 


\section{Results and Discussion}

The antifungal, antibacterial and brine shrimp lethality activities of Schinopsis brasiliensis extracts EER, EES and EEL were evaluated, and their corresponding results are shown in TABLE 1. As noted, the EER, EES and EEL extracts were inactive against Fusarium solani, displaying MIC values above $1 \mathrm{mg} / \mathrm{mL}$.

TABLE 1 also presents the Minimum Inhibitory Concentrations (MIC) of the S. brasiliensis ethanolic extracts obtained by the broth micro-dilution method against six phytopathogenic bacteria, displaying MIC values in the range from 312.5 to $10,000 \mu \mathrm{g} \cdot \mathrm{mL}^{-1}$. The leaf extract exhibited a lower MIC against three of the microorganisms tested: Ralstonia solanacearum (Race 2, B19), A. avenae subsp. citrulli (Aac1.12) and $X$. campestris pv. campestris (Xcc56). The stem extract was efficient against only the bacteria $R$. solanacearum (Race 1, CGH12), having a MIC of $312.5 \mu \mathrm{g} \cdot \mathrm{mL}^{-1}$. The leaf, stem and root extracts were equally efficient against $X$. campestris pv. campestris (Xcc56). From all the bacterias tested, $P$. carotovorum subsp. carotovorum (Pcc23) was the most resistant, having a MIC between 5,000 and $10,000 \mu \mathrm{g} \cdot \mathrm{mL}^{-1}$ for all three of the $S$. brasiliensis extracts assayed. This result allowed us to consider EER, EES and EEL to be inactive against this bacterium according to the criteria established by Tegos and collaborators (2002). The root extract displayed a MIC of $625 \mu \mathrm{g} \cdot \mathrm{mL}^{-1}$ against the bacteria $X$. campestris pv. campestris (Xcc56) and $A$. avenae subsp. citrulli (Aac1.12), and of $1,250 \mu \mathrm{g} \cdot \mathrm{mL}^{-1}$ against the bacteria $X$. campestris pv. viticola (Xcv112) and $R$. solanacearum (Race 1, CGH12). We also noted that the stem extract presented the highest MIC values against the majority of the assayed bacteria, with the exception of $X$. campestris pv. campestris (Xcc56) and $R$. solanacearum (Race 1, CGH12), against which the extract reached a MIC value of 625 and $312.5 \mu \mathrm{g} \cdot \mathrm{mL}^{-1}$, respectively. Additionally, the $S$. brasiliensis leaf extract presented the best performance, being capable of inhibiting the growth of the microorganism $A$. avenae subsp. citrulli (Aac1.12), with a MIC value of $312.5 \mu \mathrm{g} \cdot \mathrm{mL}^{-1}$. In general, these results demonstrate the good aptitude of $S$. brasiliensis extracts to inhibit the growth of the evaluated phytopathogenic bacteria

EEL was the most active extract against the phytopathogenic bacteria assayed. It was submitted to a phytochemical study aiming to identify the chemical entity(ies) responsible for its antibacterial activity. This extract was fractionated on a silica ge column, which provided triterpene glutinol (1) and a pyrocatechol 2 (FIGURE 1), whose structures were determined by comparison of their $\mathrm{IR},{ }^{1} \mathrm{H}$ and ${ }^{13} \mathrm{C}$ NMR data with those available in the literature (Tuan, Hung and Chien 2005; Sargent, Wangchareontrakul and Jefferson, 1989). To the best of our knowledge, this paper is the first to report the occurrence of both natural products $\mathbf{1}$ and $\mathbf{2}$ in Schinopsis brasiliensis. When compounds $\mathbf{1}$ and $\mathbf{2}$ were assayed against the same phytopathogenic bacteria, neither was found to be active, with MIC values above $5,000 \mu \mathrm{g} \cdot \mathrm{mL}^{-1}$ (TABLE 1). These results indicate that the most potent antibacterial activity observed for EEL is not attributed to these isolated compounds, although they may take part in a likely synergism or potentiation when present in this extract, and thus deserve further studies to clarify this possibility. Furthermore, Saraiva and collaborators (2011) and Chaves and collaborators (2011) attributed the antimicrobial activity of Schinopsis brasiliensis to the high concentration of phenolic compounds, such as tannins and flavonoids, which could not be isolated from EEL in our attempts described in this present paper. 

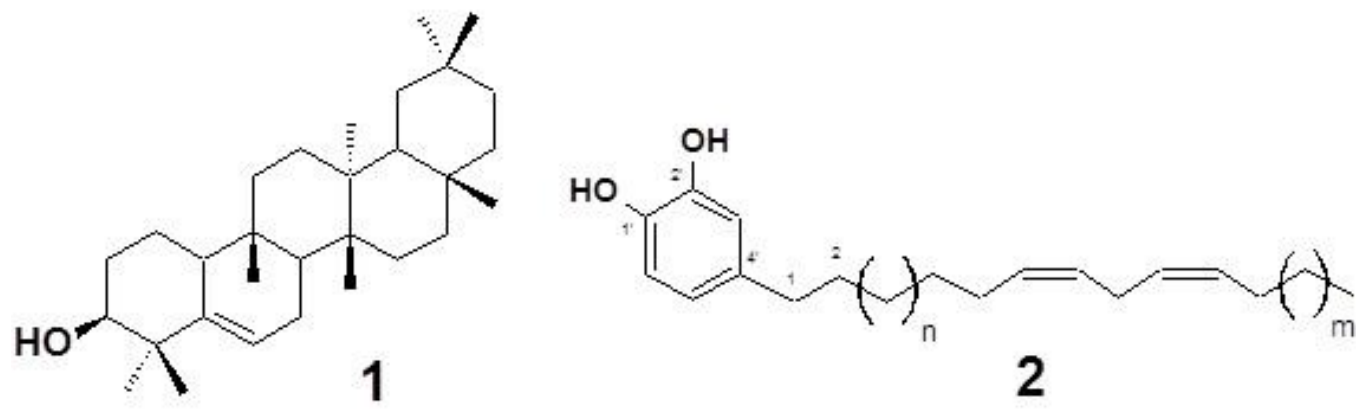

FIGURE 1. Chemical structures of compounds glutinol (1) and pyrocatechol 2 isolated from Schinopsis brasiliensis leaves.

The preliminary results (data not shown) suggest that all of the extracts from Schinopsis brasiliensis might be acting as bacteriostatic agents. From the point of view of their potential application in agriculture, these findings are important results because apart from controlling the disease caused by the phytopathogens, they also have a lower environmental impact due to the lack of more toxic residues that would rest on the agricultural products. The presence of bactericidal antibiotic substances would damage the local biodiversity and the health of the consumers of these products. As an example, copper sulfate, which is also a bacteriostatic agent, is largely used to control phytopathogens in agriculture and has low toxicity compared to other pesticides (Legaspi and Zenz, 1994).

TABLE 1. Antimicrobial and brine shrimp lethality (BSL) activities of Schinopsis brasiliensis extract EER, EES and EEL, and substances 1 and $\mathbf{2}$ against some phytopathogens and Artemia salina.

\begin{tabular}{|c|c|c|c|c|c|c|c|c|}
\hline \multirow{2}{*}{ Sample } & \multirow{2}{*}{$\begin{array}{c}\text { Fungus * } \\
\text { F. solani } \\
\text { (MIC, } \mathrm{mg} / \mathrm{mL})\end{array}$} & \multicolumn{6}{|c|}{ Bacteria (MIC, $\mu \mathrm{g} / \mathrm{mL}$ ) \# } & \multirow{2}{*}{$\begin{array}{l}\text { A. salina } \\
\left(\mathrm{LC}_{50}, \mu \mathrm{g} / \mathrm{mL}\right)\end{array}$} \\
\hline & & X.c. (I) a & X.c. (II) ${ }^{\mathrm{b}}$ & P.c. ${ }^{c}$ & R.s. (I) ${ }^{d}$ & R.s. (II) ${ }^{\mathrm{e}}$ & A.a. ${ }^{f}$ & \\
\hline EER $^{1}$ & $>1.0$ & 625 & 1,250 & 5,000 & 1,250 & 2,500 & 625 & $>1000$ \\
\hline EES $^{2}$ & $>1.0$ & 625 & 2,500 & 10,000 & 312.5 & 10,000 & 2,500 & $>1000$ \\
\hline $\mathrm{EEL}^{3}$ & $>1.0$ & 625 & 1,250 & 5,000 & 625 & 1,250 & 312.5 & $>1000$ \\
\hline 1 & & & $>5,000$ & & & & & \\
\hline 2 & & $>5,000$ & $>5,000$ & $>5,000$ & $>5,000$ & $>5,000$ & $>5,000$ & \\
\hline $\mathrm{K}_{2} \mathrm{HPO}_{3}$ & 0.001 & & & & & & & \\
\hline Gentamicin & & 0.250 & 0.031 & 0.031 & 0.031 & $>4.00$ & 0.031 & \\
\hline Lapachol & & & & & & & & 68.1 \\
\hline \multicolumn{9}{|c|}{ * Using the mycelial growth inhibition method in dishes; $\quad$ " Using the broth micro-dilution technique. } \\
\hline \multicolumn{9}{|c|}{$\begin{array}{l}\text { Phytopathogenic bacteria: a Xanthomonas campestris pv. campestris (Xcc56); }{ }^{\mathrm{b}} \text { Xanthomonas campestris pv. viticola } \\
\text { (Xcv112); }{ }^{\mathrm{c}} \text { Pectobacterium carotovorum subsp. carotovorum (Pcc23); }{ }^{d} \text { Ralstonia solanacearum (Race 1) (CGH12); }\end{array}$} \\
\hline
\end{tabular}


Papadopoulos and collaborators (2004) reported the presence of glutathione S-transferase (GST) as an internal detoxification system in the three development phases (24h, $48 \mathrm{~h}$ and adults) of Artemia salina, which are affected by a number of internal or external factors, therefore changing the organism's susceptibility to various environmental contaminants. For this reason, this micro-crustacean is a valid model to evaluate the toxicity of xenobiotics against vertebrates and invertebrates (Brophy et al., 1989; Grant and Matsumura, 1988) and can be used as a valid tool to evaluate the ecotoxicity of antimicrobial agents and plant extracts (Nunes et al., 2006). When the ecotoxicity of $S$. brasiliensis extracts was evaluated using the BSL bioassay against $A$. salina, the $L_{50}$ values were above $1,000 \mu \mathrm{g} / \mathrm{mL}$ for all of the extracts and there were no deaths of the microcrustacean's larvae up to the highest concentration assayed, indicating that these extracts are non-toxic for $A$. salina (TABLE 1) and potentially non-toxic to the environment.

Our results indicate the potential application of Schinopsis brasiliensis for agricultural use as a botanical agent to control plant diseases caused by phytopathogenic bacteria pertaining to the genera Xanthomonas, Ralstonia and Acidovorax. Further studies are still needed to confirm the in vivo antibacterial activity of these extracts.

\section{Conclusions}

This work reports the in vitro antibacterial activity of Schinopsis brasiliensis extracts against five strains of phytopathogenic bacteria and shows that such extracts are potentially non-toxic to the environment. Moreover, the triterpene glutinol and a pyrocathecol are described here for the first time as the chemical constituents of $S$. brasiliensis. The results suggest that this plant has potential for agricultural use to control plant diseases caused by phytopathogenic bacteria belonging to the genera Xanthomonas, Ralstonia and Acidovorax.

\section{Acknowledgements}

The authors are grateful to FAPESB (PET0009/2012) for grants and financial support. Prof. Dr. Elineide Barbosa de Souza and the Phytobacteriology Laboratory of the Rural Federal University of Pernambuco (UFRPE) are fully acknowledged for the donation of standard bacteria strains.

\section{References}

AGRIOS, G.N. 2005. Plant Pathology. Elsevier Academic Press. San Diego.

ALBUQUERQUE, U.P.; MEDEIROS, P.M.; ALMEIDA, A.L.S.; MONTEIRO, J.M.; LINS NETO, E.M.F.; MELO, J.G.; SANTOS, J.P. 2007. Medicinal plants of the caatinga (semi-arid) vegetation of $\mathrm{NE}$ Brazil: a quantitative approach. Journal of Ethnopharmacology, v. 114, p. 325-354.

ALVES, E.S.S.B.; PUPO, M.S.; MARQUES, S.S.; VILCHES, T.T.B.; SANTOS, R.B.; VENTURA, J.A.; FERNANDO, P.M.A. 2003. Avaliação de óleos essenciais na inibição do crescimento de fungos de fruteiras tropicais. Fitoplatologia Brasileira, v.28, p. 343-345.

AMARAL M.F.Z.J.; BARA, M.T.F. 2005. Avaliação da atividade antifúngica de extratos de plantas sobre o crescimento de fitopatógenos. Revista Eletrônica de Farmácia, v.2, p. 5-8.

ANDREWS, J.M. 2001. Determination of minimum inhibitory concentrations. Journal of Antimicrobial Chemotherapy, v. 48, p. 5-16.

BATISTA, R.; BRANDÃO, G.C.; BRAGA, F.C.; OLIVEIRA, A.B. 2009. Cytotoxicity of Wedelia 
paludosa D.C. extracts and constituents. Revista Brasileira de Farmacognosia, v.19, p. 36-40.

BROPHY, P.M.; PAPADOPOULOS, A.; TOURAKI, M.; COLES, B.; KORTING, W.; BARRETT, J. 1989. Purification of cytosolic glutathione transferases from Schistocephalus solidus (plerocercoid): interaction with anthelmintic and products of lipid peroxidation. Molecular Biochemical Parasitology, v. 36, p.187-196.

CARDOSO, M.P.; DAVID, J.M.; DAVID, J.P. 2005. A new alkyl phenol from Schinopsis brasiliensis. Natural Product Research, v.19, p.431-433.

CHAVES, T.P.; DANTAS, I.C.; FELISMINO, D.C.; VIEIRA, K.V.M.; CLEMENTINO, E.L.C.; COSTAS, L.S. 2011. Atividade antimicrobiana das folhas de Schinopsis brasiliensis Engler. Biofar, Revista de Biologia e Farmácia, v. 5, p.11-17.

CLINICAL AND LABORATORY STANDARDS INSTITUTE 2009. Methods for Dilution Antimicrobial Susceptibility Tests for Bacteria That Grow Aerobically. Approved Standard, Eighth Edition. CLSI document M7-A8. Clinical and Laboratory Standards Institute, Wayne, PA.

DAVIES, B.; BAULCOMBE, D.; CRUTE, I.; DUNWELL, J.; GALE, M.; JONES, J.; PRETTY, J.; SUTHERLAND, W.; TOULMIN, C. 2009. Reaping the Benefits: Science and the sustainable intensification of global agriculture. Royal Society, London.

DI PIERO, R.M.; NOVAES, Q.S.; PASCHOLATI, S.F. 2010. Effect of Agaricus brasiliensis and Lentinula edodes mushrooms on the infection of passionflower with Cowpea aphid-borne mosaic virus. Brazilian Archives of Biology Technology, v. 53, p. 269-278.

FINNEY, D.J. 1971. Probity analysis. Cambridge University Press. Cambridge.
GRANT, D.F.; MATSUMURA, F. 1988. Glutathione S-transferase-1 in Aedes aegypti larvae: purification and properties. Insect Biochemistry, v. 18, p.615-622.

KHAMNA, S.; YOKOTA, A.; LUMYONG, S. 2009. Actinomycetes isolated from medicinal plant rhizosphere soils: diversity and screening of antifungal compounds, indole-3-acetic acid and siderophore production. World Journal of Microbiology and Biotechnology, v. 25, p. 649-655.

KHAN, M.R. 2008. Plant Nematodes: Methodology, Morphology, Systematics, Biology and Ecology. Science publishers. Enfield, NH.

KIMATI, H.; FERNANDES, N.G.; SOAVE, J.; KUROZAWA, C.; BRIGNANI NETO, F.; BETTIOL, W. 1997. Guia de Fungicidas Agrícolas. Recomendações por Cultura [Agricultural Fungicide Guide. Recommendations by Culture]. Grupo Paulista de Fitopatologia. Jaboticabal.

LEGASPI, J.A.; ZENZ, C. 1994 - Occupational health aspects of pesticides. In: ZENZ, C.; DICKERSON, O.B.; HORVATH JR., E.P: Occupational Medicine, p.617-653. Mosby-Year Book Inc. New York.

NUNES, B.S.; CARVALHO, F.D.; GUILHERMINO, L.M.; VAN STAPPEN, G. 2006. Use of the genus Artemia in ecotoxicity testing. Environmental Pollution, v. 144 , p. 453-462.

OSTROSKY, E.A.; MIZUMOTO, M.K.; LIMA, M.E.L.; KANEKO, T.M.; NISHIKAWA, S.O.; FREITAS, B.R. 2008. Methods to evaluate the antimicrobial activity and determination of minimum inhibitory concentration (MIC) for medicinal plants. Revista Brasileira de Farmacognosia, v.18, p. 301-307.

PAPADOPOULOS, A.I.; LAZARIDOU, E.; MAURIDOU, G.; TOURAKI, M. 2004. Glutathione $S$ transferase in the branchiopod Artemia salina. Marine Biology, v.144, p. 295-301. 
RONALD, P. 2011. Plant Genetics, Sustainable Agriculture and Global Food Security. Genetics Society of America, v. 188, p.11-20.

ROZWALKA, L.C.; LIMA, M.L.R.Z.C.; MIO, L.L.M.; NAKASHIMA, T. 2008. Extratos, decoctos e óleos essenciais de plantas medicinais e aromáticas na inibição de Glomerella cingulata e Colletotrichum gloeosporioides de frutos de goiaba. Ciência Rural, v.38, p. 301-307.

SARAIVA, A.M.; CASTRO, R.H.A.; CORDEIRO, R.P.; SOBRINHO, T.J.S.P.; CASTRO, V.T.N.A.; AMORIM, E.L.C.; XAVIER, H.S.; PISCIOTTANOL, M.N.S. 2011. In vitro evaluation of antioxidant, antimicrobial and toxicity properties of extracts of Schinopsis brasiliensis Engl. (Anacardiaceae). African Journal of Pharmacy and Pharmacology, v. 5, p.1724-1731.

SARGENT, M.V.; WANGCHAREONTRAKUL, S.; JEFFERSON, A. 1989. The synthesis and identification of alkenyl and alkadienyl catechols of Burmese Lac. Journal of Chemical Society, Perkin Transactions, v.1, p. 431-439.

STANGARLIN, J.R.; SCHWAN-ESTRADA, K.R.F.; CRUZ, M.E.S.; NOZAKI, M.H. 1999. Plantas medicinais e controle alternativo de fitopatógenos. Revista Biotecnologia, Ciência e Desenvolvimento, v. 11, p. 16-21.
SUFFREDINI, I.B.; SADER, H.S.; GONÇALVES, A.G.; REIS, A.O.; GALES, A.C.; VARELLA, A.D.; YOUNES, R.N. 2004. Screening of antibacterial active extracts obtained from plants native to Brazilian Amazon rain forest and Atlantic forest. Brazilian Journal of Medical and Biological Research, v. 37, p. 379-84.

SUFFREDINI, I.B.; VARELLA, A.D.; YOUNES, RN. 2007. Minimal inhibitory concentration and minimal bactericidal concentration results from three selected antibacterial plant extracts from the Amazon and Atlantic Brazilian rain forests. Revista do Instituto de Ciências e Saúde, v. 25, p. 131-132.

TEGOS, G.; STERMITZ, F.R.; LOMOVSKAYA, O.; LEWIS, K. 2002. Multidrug drug inhibitors uncover remarkable activity of plant antimicrobials. Antimicrobial Agents and Chemotherapy, v. 46, p.3133-3141.

TUAN, L.A.; HUNG, N.V.; CHIEN, N.Q. 2005. Chemical constituents of Xerospermum laevigatum Radlk. Vietnam Journal of Chemistry, v. 43, p. 643-646.

VIGO, S.C.; MARINGONI, A.C.; CAMARA, R.C.; LIMA, G.P.P. 2009. Ação de tinturas e óleos essenciais de plantas medicinais sobre 0 crestamento bacteriano comum do feijoeiro e na produção de proteínas de indução de resistência. Summa Phytopathologica, v. 35, p. 293-304. 